\title{
Acidification is an Essential Process of Cold Atmospheric Plasma and Promotes the Anti-Cancer Effect on Malignant Melanoma Cells
}

\author{
Christin Schneider ${ }^{1,+}{ }^{+}$Lisa Gebhardt ${ }^{2,+}$, Stephanie Arndt ${ }^{3}$, Sigrid Karrer ${ }^{3}$, \\ Julia L. Zimmermann ${ }^{4}$, Michael J. M. Fischer ${ }^{2,5}$ and Anja-Katrin Bosserhoff 1,6,*(D) \\ 1 Institute of Biochemistry, Emil-Fischer-Center, University of Erlangen-Nürnberg, 91054 Erlangen, Germany; \\ christin.schneider@fau.de \\ 2 Institute of Physiology and Pathophysiology, University of Erlangen-Nürnberg, 91054 Erlangen, Germany; \\ lisa.gebhardt@fau.de (L.G.); michael.jm.fischer@meduniwien.ac.at (M.J.M.F.) \\ 3 Department of Dermatology, University Hospital Regensburg, 93053 Regensburg, Germany; \\ stephanie.arndt@ukr.de (S.A.); sigrid.karrer@ukr.de (S.K.) \\ 4 Terraplasma medical GmbH, 85748 Garching, Germany; zimmermann@terraplasm.com \\ 5 Institute of Physiology, Medical University of Vienna, 1090 Vienna, Austria \\ 6 Comprehensive Cancer Center (CCC) Erlangen-EMN, 91054 Erlangen, Germany \\ * Correspondence: anja.bosserhoff@fau.de; Tel.: +49-9131-85-24190 \\ + Authors contributed equally.
}

Received: 10 April 2019; Accepted: 8 May 2019; Published: 14 May 2019

check for updates

\begin{abstract}
Background: Cold atmospheric plasma (CAP) is ionized gas near room temperature. The anti-cancer effects of CAP were confirmed for several cancer types and were attributed to CAP-induced reactive species. However, the mode of action of CAP is still not well understood. (2) Methods: Changes in cytoplasmic $\mathrm{Ca}^{2+}$ level after CAP treatment of malignant melanoma cells were analyzed via the intracellular $\mathrm{Ca}^{2+}$ indicator fura-2 AM. CAP-produced reactive species were determined by fluorescence spectroscopic and protein nitration by Western Blot analysis. (3) Results: CAP caused a strong acidification of water and solutions that were buffered with the so-called Good buffers, while phosphate-buffered solutions with higher buffer capacity showed minor $\mathrm{pH}$ reductions. The CAP-induced $\mathrm{Ca}^{2+}$ influx in melanoma cells was stronger in acidic $\mathrm{pH}$ than in physiological conditions. NO formation that is induced by CAP was dose- and $\mathrm{pH}$-dependent and CAP-treated solutions only caused protein nitration in cells under acidic conditions. (4) Conclusions: We describe the impact of CAP-induced acidification on the anti-cancer effects of CAP. A synergistic effect of CAP-induced ROS, RNS, and acidic conditions affected the intracellular $\mathrm{Ca}^{2+}$ level of melanoma cells. As the microenvironment of tumors is often acidic, further acidification might be one reason for the specific anti-cancer effects of CAP.
\end{abstract}

Keywords: cold atmospheric plasma; malignant melanoma; calcium signaling; acidification; nitration

\section{Introduction}

Cold atmospheric plasma (CAP) is ionized gas near room temperature, which is produced at an atmospheric pressure. It consists of reactive oxygen (ROS) and reactive nitrogen (RNS) species, charged particles, and an optical emission also in the UV range [1]. It is well known that CAP shows antibacterial, antiviral, and antifungal effects, and it can therefore be used for disinfection or sterilization of, for instance, hands or surgical instruments [2-6]. CAP can promote the healing of chronic wounds due to its antibacterial activity [7] and by inducing angiogenesis and wound healing relevant molecules, like interleukin 8 [8-10]. CAP has the potential to be a new promising therapy for several cancer 
types, including malignant melanoma [11]. Malignant melanoma is one of the most aggressive cancer diseases, because of its high malignancy and therapy resistance. Although it is responsible for only $2 \%$ of all skin cancers, over $75 \%$ of skin cancer deaths were attributed to a melanoma disease [12]. Hence, there is substantial medical need for the development of new therapeutic approaches.

The most commonly observed effect after CAP treatment of cancer cells was the induction of apoptosis, as provoked by CAP-produced ROS and RNS. In this regard, especially DNA damage and depolarization of mitochondrial membrane potential could be detected [13-17]. Interestingly, CAP-treated solutions, like medium or saline, also displayed clear anti-cancer effects [18-20]. One special feature of CAP is its high selectivity against cancer cells [21-23]. Moreover, CAP also showed the killing effects on chemo-resistant cancer cells in vitro and in vivo and, in some cases, CAP-induced restoration of chemo-sensitivity was described [14,24,25].

Our group determined dose-dependent effects of CAP on malignant melanoma cells using a surface micro-discharge (SMD) plasma device [13]. In that study, a longer CAP application (2 min) caused DNA damage and apoptosis, while a shorter CAP application (1 min) induced senescence. Recently, we demonstrated that the direct and indirect CAP treatment of melanoma cells causes a $\mathrm{Ca}^{2+}$ influx that is derived from intracellular stores, which trigger the induction of CAP-induced senescence [26]. Interestingly, the addition of CAP-treated solution after an incubation time of $1 \mathrm{~h}$ also led to a cytoplasmic $\mathrm{Ca}^{2+}$ elevation. Thus, we assume that mainly long-lived CAP-produced ROS and RNS are the cause of the CAP-induced $\mathrm{Ca}^{2+}$ influx in malignant melanoma cells.

Until today, the molecular background of CAP on cancer cells and the exact involved species are not well understood. Moreover, a comparison of plasma effects is hardly possible, because of the use of distinct plasma sources resulting in different plasma components [27]. The purpose of this study was to narrow down the reactive species that are involved in $\mathrm{CAP}$-induced $\mathrm{Ca}^{2+}$ influx, and thus, to get a deeper understanding of the mode of action of CAP on cancer cells.

\section{Results}

\subsection{Effects of Different Solutions on CAP-Induced $\mathrm{Ca}^{2+}$ Influx}

CAP generates highly reactive molecules. Different physiological buffers were tested, as these differ in buffering capacity as well as in chemical composition, which was assumed to impact the generated molecules. First, we analyzed the impact of different physiological buffer compositions on the CAP-induced $\mathrm{Ca}^{2+}$ influx on malignant melanoma cells. Table 1 lists the chemical composition of the applied buffers. Mel Im and Mel Juso cells were washed with the respective solution for $5 \mathrm{~min}$. and changes in the cytoplasmic $\mathrm{Ca}^{2+}$ content were measured after $30 \mathrm{~s}$ CAP treatment using the intracellular $\mathrm{Ca}^{2+}$ indicator fura-2 AM (Figure 1). In all of the tested solutions, CAP-induced a cytosolic $\mathrm{Ca}^{2+}$ increase $(p<0.001$ each, $t$-tests single sample vs. no change). In particular, CAP exposure for 30 s caused a $\mathrm{Ca}^{2+}$ influx in both cell lines in phosphate-buffered saline (PBS) (\#1), but less than in extracellular solution (ECS) that was buffered with 4-(2-hydroxyethyl)-1-piperazineethanesulfonic acid HEPES (\#2), commonly used for cellular experiments (Mel Im ANOVA, $\mathrm{F}_{(4.2344)}=488, p<0.001$, honestly significant difference (HSD) post-hoc test, Mel Juso ANOVA, $\mathrm{F}_{(4.1682)}=1366, p<0.001$, HSD post-hoc test). These solutions mainly differ in their buffer system (HEPES vs. phosphate) and in the presence or absence of glucose. The experiments were performed in ECS HEPES solution with (\#2) and without glucose (\#3) to investigate a possible dependence on this factor. CAP-induced Ca ${ }^{2+}$ influx in Mel Im cells in the absence of glucose was decreased and the $\mathrm{Ca}^{2+}$ response was significantly delayed ( $p<0.001$, HSD post-hoc test). There was no difference between the $\mathrm{Ca}^{2+}$ response in the ECS HEPES solution with (\#2) or without (\#3) glucose in Mel Juso cells ( $p=0.99$, HSD post-hoc test). The $\mathrm{Ca}^{2+}$ response in phosphate-buffered extracellular solution (pbECS, \#4), as used previously [26], was about half of the response in the ECS HEPES solution (\#2, Mel Im and Mel Juso, $p<0.001$ each, HSD post-hoc test), but higher than in PBS (\#1, Mel Im and Mel Juso, $p<0.001$ each, HSD post-hoc test). The buffer system used had an impact on CAP-induced $\mathrm{Ca}^{2+}$ influx, which was either due 
to differences in production or due to the stability of chemical species. Therefore, we tested the effect of HEPES on CAP-induced $\mathrm{Ca}^{2+}$ influx by comparing pbECS solution (\#4) with an additionally HEPES-buffered solution (pbECS + HEPES, \#5). When compared to the combined buffering, the omission of the phosphate buffering component increased responses (Mel Im and Mel Juso, $p=0.001$ each, HSD post-hoc tests), but the omission of the HEPES increased responses in Mel Juso ( $p=0.001$, HSD post-hoc test), but not in Mel Im ( $p=0.99$, HSD post-hoc test).
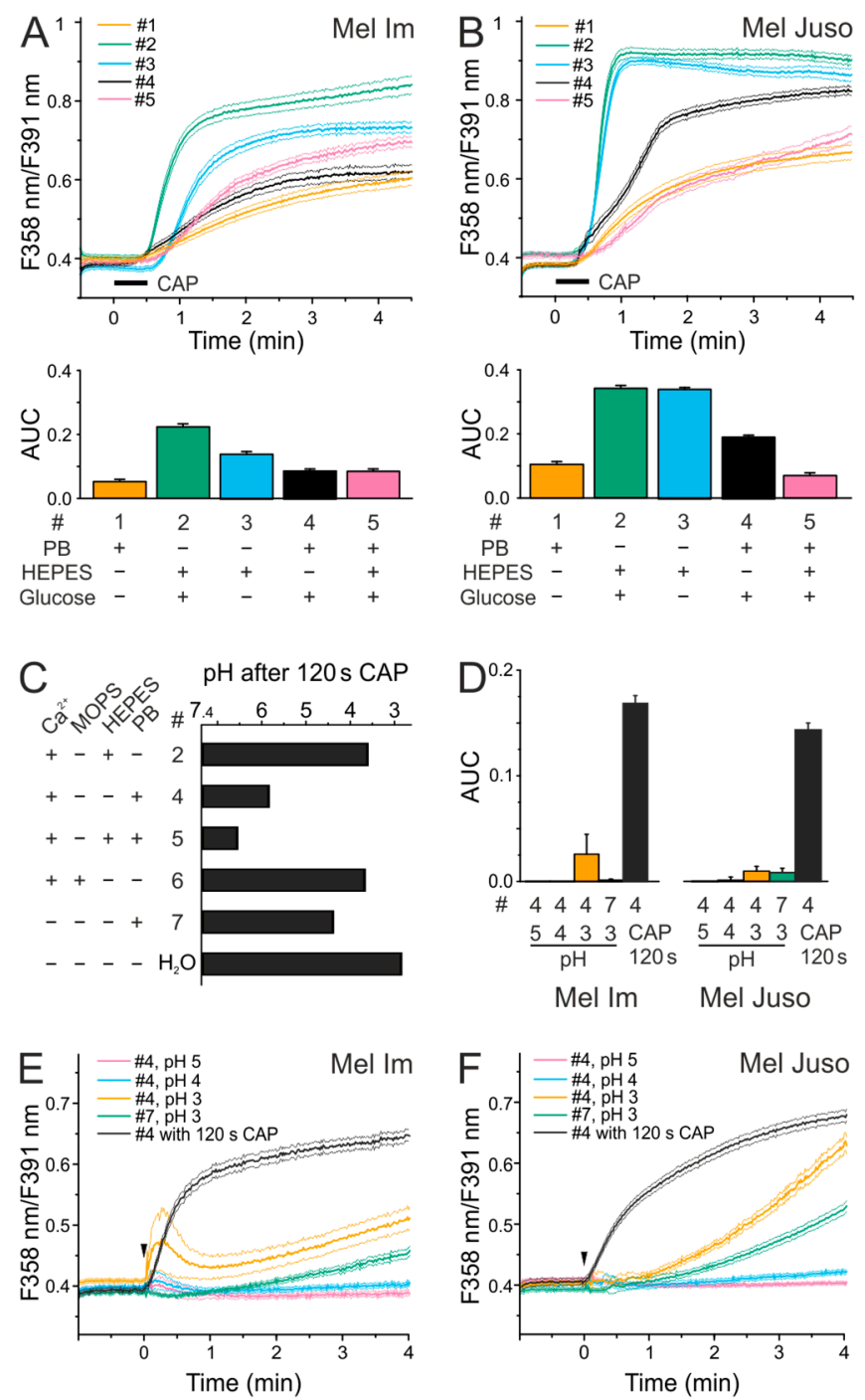

Figure 1. The intensity of cold atmospheric plasma (CAP)-induced $\mathrm{Ca}^{2+}$ influx depends on the composition of the solutions and CAP causes an acidification. $(\mathbf{A}, \mathbf{B})$ Analysis of the effect of different solutions on $30 \mathrm{~s}$ CAP-induced changes in cytoplasmic $\mathrm{Ca}^{2+}$ level of melanoma cells. (A) Mel Im $(n=137-660)$ and $(\mathbf{B})$ Mel Juso $(n=86-500)$ cells were washed in the $\mathrm{Ca}^{2+}$-containing solutions 1,2 , 3,4 , or 5 (\#4 data identical to Figure 1 in [26]). After the removal of the respective solutions, cells were treated with $30 \mathrm{~s}$ CAP. Traces represent mean and the $99 \%$ confidence interval (CI) of the mean. (C) The solutions \#2, 4, 5, 6, 7 or bidestilled water ( $\mathrm{pH} 7.4$ ) were exposed to $120 \mathrm{~s} \mathrm{CAP}$ as $7 \times 20 \mu \mathrm{L}$ drops. Measurement of $\mathrm{pH}$ was performed in a $1.5 \mathrm{~mL}$ reaction vessel. Data are shown as mean. (D-F). Analysis of the effect of an acidic $\mathrm{pH}$ on cytoplasmic $\mathrm{Ca}^{2+}$ levels of Mel Im ((D,E), $\left.n=485-999\right)$ and Mel Juso ((D,F), $n=275-376)$ cells. $100 \mu \mathrm{L}$ of pbECS (\#4; pH 3,4,5) and pbECS - Ca ${ }^{2+}$ (\#7; pH 3) was added onto melanoma cells (indicated by an arrow). The application of $100 \mu \mathrm{L}$ of $120 \mathrm{~s}$ CAP-treated pbECS (\#4) to Mel Im ((D,E), $n=485)$ and Mel Juso $((\mathbf{D}, \mathbf{F}), n=321)$ cells served as control. Phosphate-buffered $(\mathrm{PB})$, area under the curve (AUC), fluorescence intensity $(\mathrm{F})$. 
Table 1. Composition of the used solutions with concentrations in $\mathrm{mM}$ and an assigned solution number used throughout the manuscript.

\begin{tabular}{|c|c|c|c|c|c|c|c|c|}
\hline Solution & $\begin{array}{c}\text { PBS } \\
\# 1\end{array}$ & $\begin{array}{c}\text { ECS } \\
\text { HEPES } \\
\# 2\end{array}$ & $\begin{array}{c}\text { ECS HEPES - } \\
\text { Glucose } \\
\# 3\end{array}$ & $\begin{array}{c}\text { pbECS } \\
\# 4\end{array}$ & $\begin{array}{c}\text { pbECS + } \\
\text { HEPES } \\
\# 5\end{array}$ & $\begin{array}{l}\text { ECS } \\
\text { MOPS } \\
\# 6\end{array}$ & $\begin{array}{l}\text { pbECS } \\
-\mathrm{Ca}^{2+} \\
\# 7\end{array}$ & $\begin{array}{c}\text { pbECS }-\mathrm{Ca}^{2+} \\
3 \times \text { Buffered } \\
\# 8\end{array}$ \\
\hline $\mathrm{NaCl}$ & 137.9 & 145.0 & 145.0 & 133.0 & 133.0 & 145.0 & 133.0 & 108.8 \\
\hline $\mathrm{KCl}$ & 2.5 & 5.0 & 5.0 & 3.5 & 3.5 & 5.0 & 3.5 & 0.6 \\
\hline Glucose & & 10.0 & & 10.0 & 10.0 & 10.0 & 10.0 & 10.0 \\
\hline $\mathrm{KH}_{2} \mathrm{PO}_{4}$ & 2.5 & & & 1.5 & 1.5 & & 1.5 & 4.4 \\
\hline $\mathrm{Na}_{2} \mathrm{HPO}_{4}$ & 7.0 & & & 8.1 & 8.1 & & 8.1 & 24.2 \\
\hline $\mathrm{CaCl}_{2}$ & 1.3 & 1.3 & 1.3 & 1.3 & 1.3 & 1.3 & & \\
\hline $\mathrm{MgCl}_{2}$ & 1.0 & 1.0 & 1.0 & 1.0 & 1.0 & 1.0 & 1.0 & 1.0 \\
\hline EGTA & & & & & & & 10.0 & 10.0 \\
\hline HEPES & & 10.0 & 10.0 & & 10.0 & & & \\
\hline MOPS & & & & & & 10.0 & & \\
\hline
\end{tabular}

\subsection{CAP Causes a Decrease in $\mathrm{pH}$ but Acidic Solutions Have No Effects on Cytoplasmatic Ca ${ }^{2+}$ Level}

As more buffering capacity seemed to reduce the CAP-induced $\mathrm{Ca}^{2+}$ influx, we analyzed whether CAP changes the $\mathrm{pH}$ value of the solutions. A CAP dose of $120 \mathrm{~s}$ decreases the $\mathrm{pH}$ of 7.4 of all the solutions tested $(p<0.030$ each, $t$-tests, Figure 1C). The strongest acidification after CAP treatment was observed in water $\left(\mathrm{H}_{2} \mathrm{O}\right)$, resulting in a $\mathrm{pH}$ of 3 . The solutions that were only buffered with $10 \mathrm{mM}$ of the so-called Good buffers HEPES (\#2) or MOPS (\#6), showed a pH lower than 4 (Figure 1C). Phosphate-buffered solutions with and without HEPES showed the slightest acidification with $\mathrm{pH}$ values of about 6 (pbECS, \#4) and 6.5 (pbECS + HEPES, \#5). Interestingly, pbECS without $\mathrm{Ca}^{2+}(\# 7)$ resulted in a more acidic $\mathrm{pH}$ when compared to the pbECS with $\mathrm{Ca}^{2+}(\# 4, p=0.004, T$-test independent samples).

Next, we asked whether acidic solutions trigger a $\mathrm{Ca}^{2+}$ influx in melanoma cells (ANOVA, $\mathrm{F}_{(4.1960)}=485$ and Mel Juso ANOVA, $\left.\mathrm{F}_{(4.1603)}=1340\right)$. When compared to the $\mathrm{Ca}^{2+}$ increase by a solution exposed to CAP for $120 \mathrm{~s}$, application of acidic solutions caused no biologically relevant $\mathrm{Ca}^{2+}$ increase (Mel Im and Mel Juso, $p<0.001$ each, HSD post-hoc tests, Figure 1D-F). To address this further, the application of pbECS (\#4) $\mathrm{pH} 5$ or $\mathrm{pH} 4$ caused no $\mathrm{Ca}^{2+}$ increase (n.s.) and $\mathrm{pH} 3$ a slow and gradual increase (marginal as compared to CAP $120 \mathrm{~s}, 15 \%$ in Mel Im and 6\% in Mel Juso, $p<0.001$, $t$-test independent sample, Figure 1E,F). In summary, an acidic $\mathrm{pH}$ alone cannot explain the differences in the $\mathrm{Ca}^{2+}$ response after CAP treatment.

\subsection{CAP Causes a Lower $\mathrm{Ca}^{2+}$ Influx at Physiological $p H$ Than Under Acidic Conditions}

We tested higher buffer concentrations, as the single HEPES- and MOPS-buffered solutions showed the strongest acidification by $120 \mathrm{~s}$ of CAP treatment. The CAP-induced acidification decreased with increasing concentration of HEPES ( $\# 2, \mathrm{R}=0.97, p<0.001$, product-momentum correlation, Figure $2 \mathrm{~A}$ ) and MOPS (\#6, $\mathrm{R}=0.90, p=0.007$, product-momentum correlation, Figure $2 \mathrm{~B}$ ). While the ECS solution with $20 \mathrm{mM}$ HEPES or MOPS had a pH of 4.6 or 5.4 after $120 \mathrm{~s}$ CAP, a doubling of the buffer concentration led to a minor CAP-induced $\mathrm{pH}$ decrease, with $\mathrm{pH}$ values of about 6.6 for both solutions. A buffer concentration of 60 or $80 \mathrm{mM}$ HEPES or MOPS largely abolished the CAP-induced $\mathrm{pH}$ reduction. $\mathrm{Ca}^{2+}$ imaging experiments with the different ECS HEPES (\#2)/MOPS (\#6) solutions showed that the $\mathrm{Ca}^{2+}$ influx after $30 \mathrm{~s}$ CAP decreases with an increasing buffer concentration in Mel $\operatorname{Im}(p<0.001$ each, product-momentum correlations, $\mathrm{R}=-0.90,-0.96$, Figure 2C,D), and Mel Juso $(p<0.001$ each, product-momentum correlations, $-0.93,-0.85$, Figure $2 \mathrm{E}, \mathrm{F})$. Using $40 \mathrm{mM}$ HEPES or MOPS, the Mel Im cells showed a greatly reduced $\mathrm{Ca}^{2+}$ response; whereas, still a marked CAP-induced $\mathrm{Ca}^{2+}$ influx was observed in the Mel Juso cells. A threefold increased phosphate amount of the $\mathrm{Ca}^{2+}$ free pbECS (\#8) solution was required for largely buffering the $\mathrm{pH}$ of a $120 \mathrm{~s}$ CAP exposure (Figure S1A). In threefold compared to onefold buffer capacity (\#8), 30 s CAP treatment caused less $\mathrm{Ca}^{2+}$ increase, 
as also observed in higher HEPES or MOPS buffer concentrations (Mel Im 18\% of onefold buffer, Mel Juso $78 \%$ of onefold buffer, $p<0.001$ each, $t$-test independent samples, Figure S1B,D). However, a substantial fraction of the response remains, even when acidification by CAP is largely buffered.
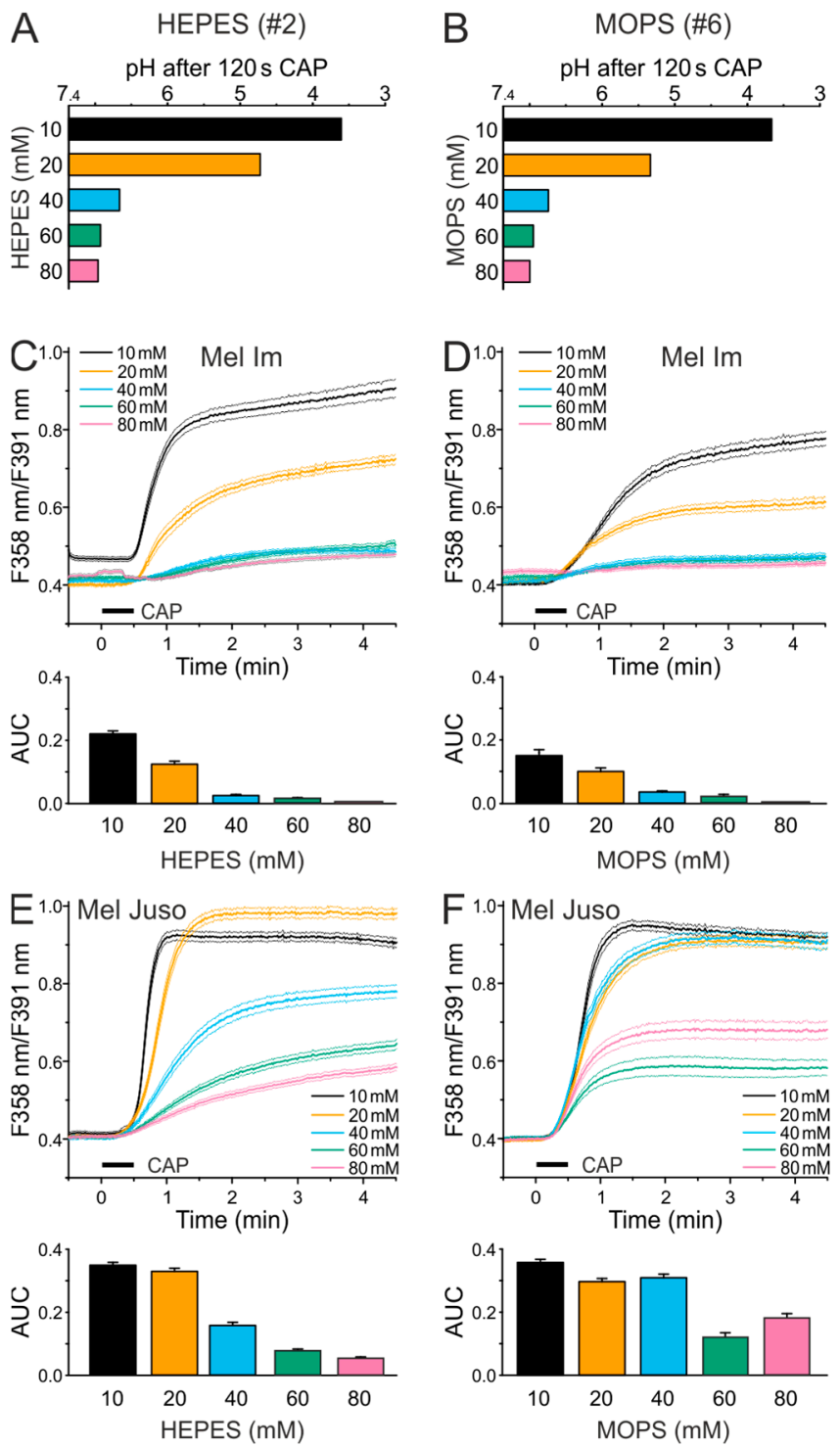

Figure 2. CAP-induced $\mathrm{Ca}^{2+}$ influx decreases in Mel Im and Mel Juso cells with increasing buffer concentration. Experiments in HEPES-buffered solutions are reported in the left panels (A,C,E), the respective experiments in MOPS-buffered solutions in the right panels $(\mathbf{B}, \mathbf{D}, \mathbf{F})$. (A,B) Measurement of the $\mathrm{pH}$ of different HEPES- $(\mathbf{A})$ and MOPS- $(\mathbf{B})$ buffered solutions $(7 \times 20 \mu \mathrm{L})$ after $120 \mathrm{~s}$ CAP treatment, using a $1.5 \mathrm{~mL}$ reaction vessel. Data are shown as mean. $(\mathbf{C}-\mathbf{F}) \mathrm{Cytoplasmic} \mathrm{Ca}^{2+}$ levels stimulated by 30 s CAP exposure of Mel Im $(n=220-603)$ and Mel Juso $(n=223-377)$ cells in different HEPES- (C,E) and MOPS- (D,F) buffered solutions.

\subsection{CAP-produced NOAlone Seems to Have No Effects on CAP-Induced $\mathrm{Ca}^{2+}$ Influx}

Next, we investigated the chemical species that are produced by different CAP exposure times in pbECS. For this purpose, measurements were performed in CAP-exposed droplets. Measurements with the ROS-sensitive dye (DHR 123) showed an increase of fluorescence intensity in CAP-treated pbECS (\#4) as compared to the untreated control ( $p<0.05$ each, U-tests, Figure $3 \mathrm{~A}) . \mathrm{A} \mathrm{H}_{2} \mathrm{O}_{2}$ production of 6-7 $\mu \mathrm{M}$ was observed in $10 \mathrm{~s}$ and longer CAP-treated pbECS (\#4) (ANOVA, $\mathrm{F}_{(4.74)}=115, p<0.001$ each, HSD post-hoc tests, Figure $3 \mathrm{~B})$. Using a singlet oxygen $\left({ }^{1} \mathrm{O}_{2}\right)$ reagent, an about twofold higher 
fluorescence when compared to the control could be observed after $10 \mathrm{~s}, 30 \mathrm{~s}$, and $60 \mathrm{~s}$ CAP $(p<0.05$ each, U-tests, Figure 3C). Interestingly, $120 \mathrm{~s}$ CAP caused a substantial further increase in ${ }^{1} \mathrm{O}_{2}$ as compared to the $60 \mathrm{~s}$ CAP (marked with a cross, $p=0.049, U$-test, Figure $3 \mathrm{C}$ ). The strongest CAP duration-dependency in pbECS (\#4) could be observed for nitric oxide (NO), which was measured with the NO indicator DAF-2. While $10 \mathrm{~s}$ CAP showed an about 5-fold increase of DAF-2 fluorescence, $30 \mathrm{~s}$ CAP treatment led to about 20-fold and $60 \mathrm{~s}$ to about 80-fold increase NO production in comparison to untreated pbECS ( $p<0.05$ each, $U$-tests, Figure 3D). As the CAP-induced $\mathrm{Ca}^{2+}$ influx was shown to increase by treatment time, one or more of the dose-dependently produced species could cause this $\mathrm{Ca}^{2+}$ response. Species measurements in Dulbecco's phosphate buffered saline (DPBS), Dulbecco's Modified Eagle Medium (DMEM), and RPMI displayed that the composition of the solutions influences the CAP-induced species production (Figure S2). When compared to pbECS, the ROS levels were similar in DPBS, and lower in DMEM and RPMI (ANOVA, $\mathrm{F}_{(3,32)}=39.3, p=0.58, p<0.001$, and $p<0.001$, HSD post-hoc tests). When compared to pbECS, $\mathrm{H}_{2} \mathrm{O}_{2}$ levels were similar in DPBS, lower in DMEM and higher in RPMI ( $p=0.72, p<0.001$ and $p<0.001$, HSD post-hoc tests). As compared to pbECS, the ${ }^{1} \mathrm{O}_{2}$ levels were lower in DPBS, higher in DMEM and similar in RPMI (ANOVA, $\mathrm{F}_{(3.32)}=61.4, p<0.001$, $p<0.001$, and $p=0.99$, HSD post-hoc tests). When compared to pbECS, NO levels were lower in all other solutions (ANOVA, $\mathrm{F}_{(3.32)}=44.8, p<0.001$ each, HSD post-hoc test).

Interestingly, we detected similar ROS as in pbECS in DPBS, but NO production was lower in DPBS. As the CAP-induced $\mathrm{Ca}^{2+}$ influx was equally lower in DPBS when compared to pbECS, NO could be important for this effect.

Interestingly, the NO scavenger 2-4-carboxyphenyl-4,4,5,5-tetramethylimidazoline-1-oxyl-3-oxide (cPTIO) had no effects on the CAP-induced $\mathrm{Ca}^{2+}$ influx (Figure 3E,F). We further tested the ROS scavenger histidine, which display quenching effects on ${ }^{1} \mathrm{O}_{2}, \mathrm{H}_{2} \mathrm{O}_{2}$, and $\bullet \mathrm{OH}[28,29]$. ROS scavenging by histidine pretreatment resulted in a strong inhibition of the $\mathrm{Ca}^{2+}$ influx in both cell lines after $30 \mathrm{~s}$ CAP ( $p<0.001$ each, $t$-test with unpaired samples, Figure $3 \mathrm{G}, \mathrm{H})$. We tested whether the scavenging of reactive species could influence the CAP-induced acidification. PH measurements in ECS (\#2) revealed no influence of $\mathrm{cPTIO}$ and histidine on the $\mathrm{pH}$ reduction by $\mathrm{CAP}$, whereas the ${ }^{1} \mathrm{O}_{2}$ scavenger sodium azide $\left(\mathrm{NaN}_{3}\right)$ reduced the acidification process (Figure $\mathrm{S} 3$ ). In a previous study, we recognized that the species that were involved in CAP-induced $\mathrm{Ca}^{2+}$ influx were stable for at least one hour [26]. $\mathrm{H}_{2} \mathrm{O}_{2}$ can be stable in solution [30]; therefore, we tested whether the $30 \mathrm{~s}$ CAP-induced $\mathrm{H}_{2} \mathrm{O}_{2}$ amount $(6 \mu \mathrm{M})$ changes the intracellular $\mathrm{Ca}^{2+}$ amount. The addition of $\mathrm{H}_{2} \mathrm{O}_{2}$ (in solution \#4) on Mel Im and Mel Juso cells had no effects on the intracellular $\mathrm{Ca}^{2+}$ level (Figure S4). However, after preexposure of the cells to $\mathrm{pH} 6$ in pbECS, $\mathrm{H}_{2} \mathrm{O}_{2}$ (\#4, pH 6) caused a weak $\mathrm{Ca}^{2+}$ influx, with response rates of only $11 \%$ and $7 \%$ (Mel Im and Mel Juso, respectively, normalized to CAP).

\subsection{An Acidic $p H$ is Necessary For the Stability of Species That are Involved in the CAP-Induced Ca ${ }^{2+}$ Influx}

We further wanted to figure out whether the acidic milieu is necessary for the stability of the relevant species of CAP-induced $\mathrm{Ca}^{2+}$ influx. The $\mathrm{pH}$ of a $120 \mathrm{~s}$ CAP-treated pbECS (\#4) was titrated back to a physiological range and the addition of this solution onto melanoma cells caused a lower $\mathrm{Ca}^{2+}$ influx than the acidic pbECS (\#4) solution ( $p<0.001$ each, t-test with unpaired samples, Figure 4A,B). Interestingly, a re-acidified 120 s CAP-treated pbECS (\#4) solution induced a similar $\mathrm{Ca}^{2+}$ response as the non-titrated acidic pbECS (\#4). The fluorescence measurements of the CAP-induced species production in pbECS (\#4) showed that the $\mathrm{pH}$ titration resulted in an increased amount of ROS, a decreased amount of $\mathrm{NO}$, and ${ }^{1} \mathrm{O}_{2}$ production was not affected $(p=0.034, p=0.026$ and $p=0.22$, respectively, $t$-test with paired samples, Figure $4 \mathrm{C}-\mathrm{E})$. The results suggest that, although $\mathrm{NO}$ alone seems to have no impact on the $\mathrm{Ca}^{2+}$ influx after direct CAP treatment, it could be a precursor of the relevant species. NO can react with superoxide $\left(\mathrm{O}_{2}{ }^{--}\right)$to form the highly reactive peroxynitrite $\left(\mathrm{ONOO}^{-}\right)$, which could induce tyrosine nitration. As shown by Western Blot analysis (Figure $\left.4 \mathrm{~F}\right)$, direct CAP treatment leads to a dose-dependent increase of 3-nitrotyrosine in Mel Im and Mel Juso cells $(\mathrm{R}=0.65, p=0.001$, product-momentum correlation). Protein nitration was further observed after the 
application of a $120 \mathrm{~s}$ CAP-treated pbECS (\#4) solution onto melanoma cells ( $p=0.028, n=3$, Wilcoxon test, Figure $4 \mathrm{G}$ ). The titration of the $\mathrm{pH}$ of $120 \mathrm{~s}$ CAP-treated pbECS (\#4) to a physiological range inhibited CAP-induced 3-nitrotyrosine induction ( $p=0.028, n=3$, Wilcoxon test), whereas protein nitration occurred after re-acidification of $120 \mathrm{~s}$ CAP-treated pbECS (\#4, $p=0.046, n=3$, Wilcoxon test). The findings indicated that the CAP-induced acidification influences the CAP-induced RNS production and, consequently, protein nitration.
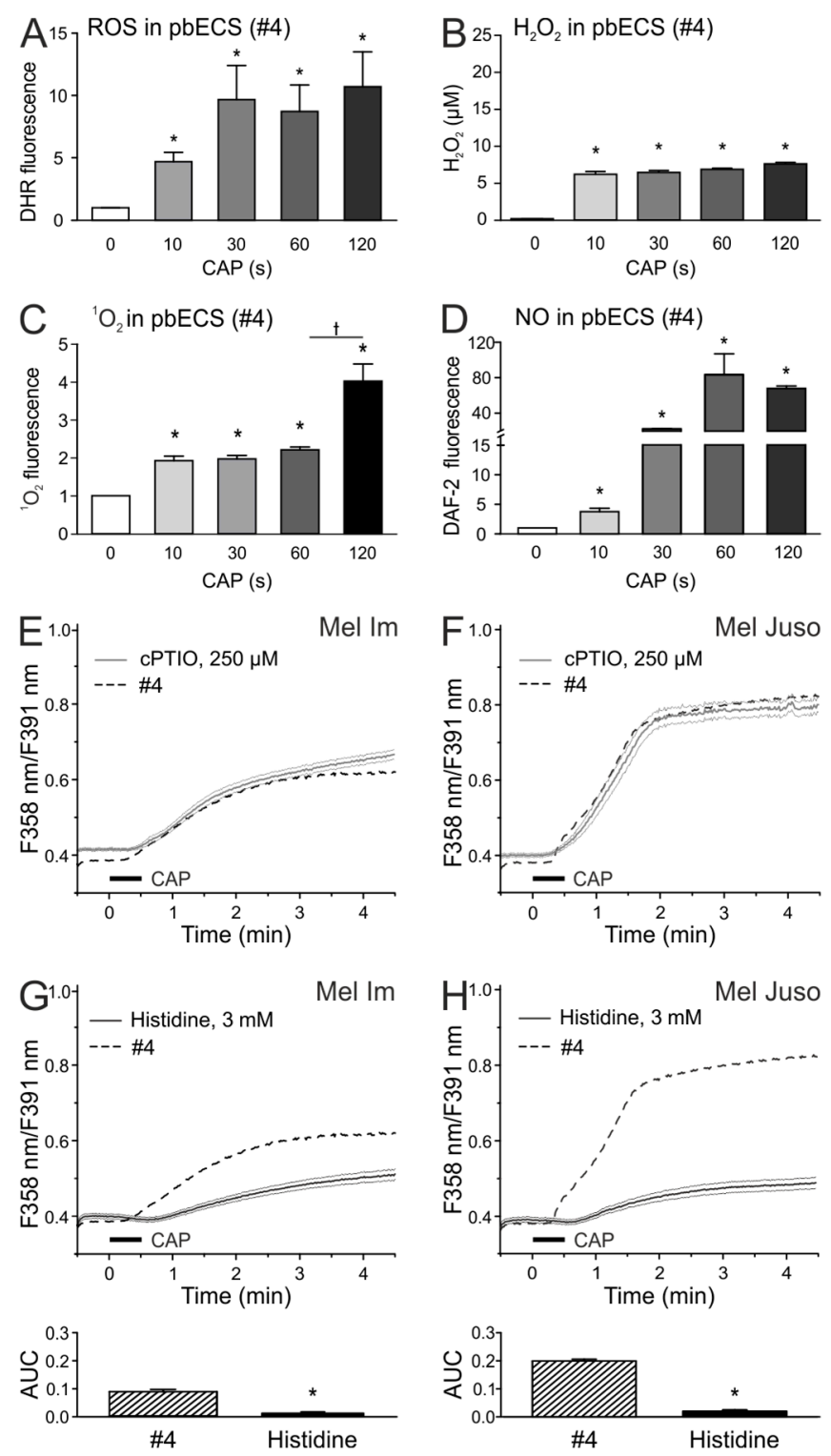

Figure 3. Histidine reduces the $\mathrm{Ca}^{2+}$ influx in CAP-treated melanoma cells, nitric oxide (NO) scavenging does not alter the CAP effect. (A-D) Fluorescence spectroscopic analysis of CAP-induced

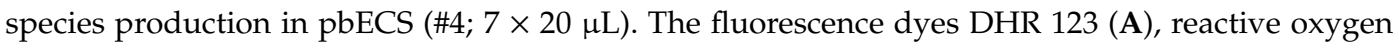
(ROS)-indicator), Singlet Oxygen Sensor Green Reagent (C) and 4,5-diaminofluorescein (DAF-2) (D), NO-indicator) were solved in pbECS (\#4) at a concentration of $10 \mu \mathrm{M}$ and exposed to different CAP-doses. (B) $\mathrm{H}_{2} \mathrm{O}_{2}$ concentration was determined in duplicates using the Fluorimetic Hydrogen Peroxide Assay Kit. (E-H). Investigation of the effect of the NO scavenger 2-4-carboxyphenyl4,4,5,5-tetramethylimidazoline-1-oxyl-3-oxide (cPTIO) $(250 \mu \mathrm{M})$ and the ROS scavenger histidine $(3 \mu \mathrm{M})$ on 30 s CAP-induced $\mathrm{Ca}^{2+}$ influx in Mel Im $((\mathbf{E}, \mathbf{G}), n=234-470)$ and Mel Juso $((\mathbf{F}, \mathbf{H}), n=84-307)$ cells. The latter traces are identical to Figure 1 in [26]. 

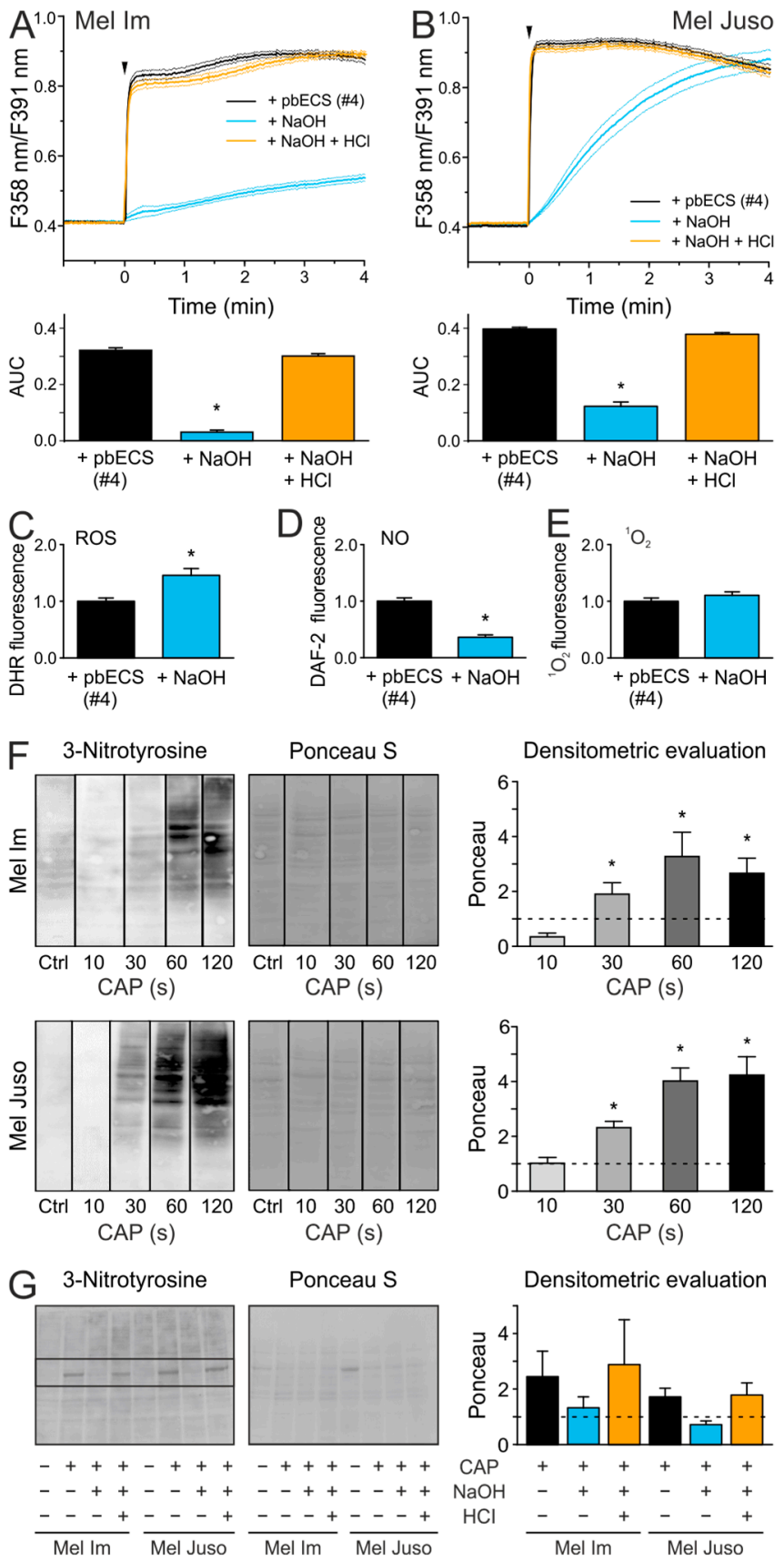

Figure 4. The stability of CAP-induced reactive species is $\mathrm{pH}$ dependent and $\mathrm{NO}$ is involved in protein nitration by $\mathrm{CAP}$ at an acidic $\mathrm{pH}$. The acidic $\mathrm{pH}(5.8)$ of pbECS (\#4) after CAP treatment was titrated to about 7.4 by $\mathrm{NaOH}(1 \mathrm{M})$ or further titrated back to a pH of about 6 using $\mathrm{HCl}(1 \mathrm{M})$. (A,B) PbECS (\#4; $7 \times 20 \mu \mathrm{L})$ treated with $120 \mathrm{~s}$ CAP was applied (arrow) to Mel $\operatorname{Im}((\mathbf{A}), n=377-442)$ and Mel Juso $((\mathbf{B})$, $n=326-390$ ) cells. (C-E) Fluorescence spectroscopic analysis of CAP-produced species in pbECS (\#4; $7 \times 20 \mu \mathrm{L})$ after $\mathrm{pH}$ titration, by using DHR $123(\mathrm{C}),(10 \mu \mathrm{M}), \mathrm{DAF}-2(\mathrm{D}),(10 \mu \mathrm{M})$, and Singlet Oxygen Sensor Green Reagent $(\mathrm{E}),(10 \mu \mathrm{M})$. The data are normalized to the respective controls (without $\mathrm{pH}$ titration). (F,G) Western Blot analysis of CAP-induced protein nitration after direct (F) and indirect (G) CAP-treatment of Mel Im and Mel Juso cells. Densitometric evaluation is shown as mean \pm SEM. The pixel intensity of each lane is shown in Table S1. 


\section{Discussion}

The microenvironment of tumors is often acidic due to metabolic alterations, like upregulation of glycolysis and the pentose phosphate pathway, and an oxygen delivery that does not match the metabolic demand [31,32]. While the extracellular $\mathrm{pH}$ of most tissues is near 7.4, the tumor microenvironment can be in a range of $\mathrm{pH} 5.4-7.4$ [33,34]. An extracellular $\mathrm{pH}$ of 6 triggers changes in cytoplasmatic $\mathrm{Ca}^{2+}$ level in cells of the skin, e.g., fibroblasts or endothelial cells, also in neuroblastoma cells, but not in the epidermoid carcinoma cell line A431 [35]. Surprisingly, a pH 4 did not induce a $\mathrm{Ca}^{2+}$ influx in melanoma cells in the present study, only with $\mathrm{pH} 3$, an influx was observed, but this is a $\mathrm{pH}$ level that causes irreversible damage in e.g., erythrocytes and nerve cells $[36,37]$. This suggests that skin cancer cells have a remarkable $\mathrm{pH}$ resistance. Nevertheless, the CAP-induced $\mathrm{Ca}^{2+}$ influx in melanoma cells was higher at an acidic $\mathrm{pH}$ than under physiological conditions, which implies a synergistic mechanism of CAP-induced species and acidification.

We observed an acidification of solutions after CAP exposure, which is in line with results from several groups [38-42]. However, the cause of this acidification, as well as its impact on the antitumor properties of CAP, is not well understood. As observed here and reported previously, a longer CAP treatment duration caused a stronger acidification [38-40]. Thus, the concentration of $\mathrm{CAP}$-induced reactive species seems to determine the level of acidification. Some groups assumed that $\mathrm{H}_{2} \mathrm{O}_{2}$, hydroperoxyl $\left(\mathrm{HO}_{2}\right)$ or peroxynitrous acid $(\mathrm{ONOOH})$ could be involved in the acidification process $[38,39,43,44]$. However, the most commonly suspected source of CAP-induced acidification was the production of nitric acid $\left(\mathrm{HNO}_{3}\right)$ and nitrous acid $\left(\mathrm{HNO}_{2}\right)$, which was due to hydrolysis of nitrogen dioxide $\left(\mathrm{NO}_{2}\right)$ (1, see reaction numbers (grey) in Figure 5) [39,45-47]. The strong acid $\mathrm{HNO}_{3}$ $\left(\mathrm{pK}_{\mathrm{a}}=-1.32\right)$ completely dissociates in water (2). The weak acid $\mathrm{HNO}_{2}\left(\mathrm{pK}_{\mathrm{a}}=3.3\right)$ only dissociates partially and it is in an acid-base equilibrium with nitrite $\left(\mathrm{NO}_{2}{ }^{-}\right)(3)[48,49]$. In accordance to our observations, $\mathrm{NaN}_{3}$ was capable of reducing CAP-induced acidification in aqueous solutions [50]. This effect was attributed to a reaction of $\mathrm{NO}_{2}{ }^{-}(4,5)$ with $\mathrm{NaN}_{3}$, which consumes protons [49-51]. The underlying mechanism strengthened our assumption that $\mathrm{HNO}_{2}$ could be co-responsible for the CAP-induced acidification.

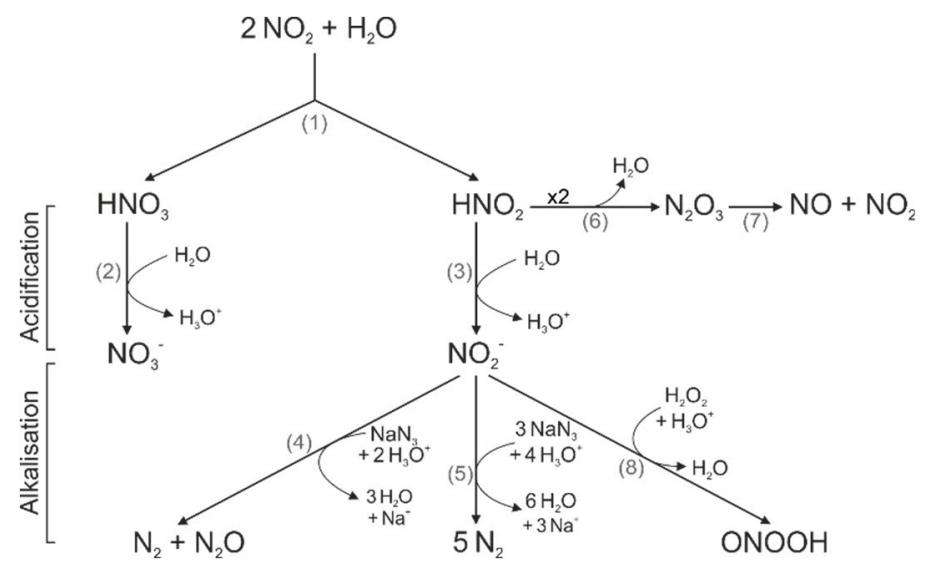

Figure 5. Schematic diagram of chemical species. The graphical reactions described in the text are represented to show acidification or consumption of acidic equivalents by $\mathrm{NaN}_{3}$ or generation of peroxynitrous acid $(\mathrm{ONOOH})$.

In the present study, the strongest CAP-induced acidification could be observed in bidestilled water. Treatment with other plasma devises also resulted in a stronger reduction in $\mathrm{pH}$ value in non-buffered solutions, like deionized water or $\mathrm{NaCl}$, when compared to the buffered solutions [38,52]. CAP-induced acidification was dependent on the type of buffer. We assume that hydronium ions from reaction (2) and (3) were removed by the phosphate buffers. Therefore, pbECS (\#4) and pbECS + HEPES (\#5) only showed a slight pH decrease after CAP-treatment. In contrast, for a relevant reduction 
of CAP-induced acidification, a four-fold higher concentration of HEPES or MOPS was needed. Good buffers can be oxidized by $\mathrm{H}_{2} \mathrm{O}_{2}$; however, the process is slow and it only occurs at a concentration of at least $0.1 \mathrm{M} \mathrm{H}_{2} \mathrm{O}_{2}$ [53]. Nonetheless, a reaction of HEPES and MOPS with CAP-produced species might be a possible explanation for their poor CAP buffering.

We further revealed that the titration of 120 s CAP-treated pbECS (\#4) to a physiological range reduces $\mathrm{CAP}$-induced $\mathrm{Ca}^{2+}$ influx and protein nitration. Back-titration to a $\mathrm{pH}$ of around 6 resulted in a complete recovery of these effects. This suggests that the relevant species were only present under acidic conditions, but are not lost in temporary more alkalic conditions. Since the addition of $\mathrm{NaOH}$ to 120 s CAP-treated pbECS (\#4) led to a reduction in NO formation, NO was one possible species being involved. The incorporation of a nitro group at the phenol ring of tyrosine can lead to several biochemical changes. For instance, a decrease in the $\mathrm{pK}_{\mathrm{a}}$ value of the hydroxyl group, the addition of steric restrictions, or local conformational changes in the protein $[54,55]$. In consequence, a loss or gain of protein function or modulation of protein activity can be the result. A well-studied example for a protein inactivation due to nitration is the mitochondrial antioxidant manganese superoxide dismutase (MnSOD) [56,57]. In strong acidic solutions $(\mathrm{pH} \approx 3.3), \mathrm{HNO}_{2}$ decomposed to dinitrogen trioxide $\left(\mathrm{N}_{2} \mathrm{O}_{3}\right)(6)$, which in turn reacts to $\mathrm{NO}$ and $\mathrm{NO}_{2}(7)[43,58,59]$.

It was shown that the $\mathrm{HNO}_{2}$-derived $\mathrm{NO}$ formation strongly depends on the $\mathrm{pH}$ value. Thereby, the amount of NO significant increased from $\mathrm{pH} 7.4$ to $\mathrm{pH} 3$ [60]. Furthermore, NO-induced nitration was described as a $\mathrm{pH}$-dependent processes, with a maximum at $\sim \mathrm{pH} 8$ and low nitration levels at acidic conditions [61]. As in the present study, CAP-induced NO production in pbECS (\#4), as well as CAP-induced 3-nitrotyrosine formation, showed a clear dose dependency; therefore, one can assume that the protein nitration by CAP was caused by $\mathrm{HNO}_{2}$-derived $\mathrm{NO}$. However, $\mathrm{NO}$ does not seem to be responsible for the $\mathrm{Ca}^{2+}$ influx, as this was not altered by the NO scavenger CPTIO.

As observed by various groups, solutions that were strongly acidified by CAP showed stronger antibacterial effects than CAP-treated solutions that were closer to physiological pH $[39,52,58,62]$. Furthermore, an acidic $\mathrm{pH}$ alone did not have the same anti-bacterial effects as a CAP-treated solution of identical $\mathrm{pH}[39,58]$. A synergetic effect of $\mathrm{NO}_{2}{ }^{-}, \mathrm{H}_{2} \mathrm{O}_{2}$, and acidic conditions was supposed to be responsible for the strong antibacterial effects of CAP [49,52,58]. One possible underlying mechanism was the production of the highly reactive $\mathrm{ONOOH}$ or $\mathrm{ONOO}^{-}$(8) [52].

In contrast to that, the importance of the CAP-induced $\mathrm{pH}$ reduction on the anticancer effects of $\mathrm{CAP}$ was largely unexplored. It has been shown that a combination of $\mathrm{H}_{2} \mathrm{O}_{2}$ and $\mathrm{HNO}_{2}$ displayed antitumor effects that are comparable to CAP $[63,64]$. Thus, similar to the bacterial studies, a synergism of these species and an acidic $\mathrm{pH}$ could be also involved in the CAP effects on cancer cells. As observed by our group, CAP caused a $\mathrm{Ca}^{2+}$ influx in mouse fibroblasts, whereas the application of $\mathrm{H}_{2} \mathrm{O}_{2}$ at an equivalent concentration to CAP production $(2.94 \mu \mathrm{M})$ had no effects [65]. In a previous study, we identified the ryanodine receptor $(\mathrm{RyR})$ of the endoplasmic reticulum as one of the involved channels in CAP-induced $\mathrm{Ca}^{2+}$ influx [26]. $\mathrm{H}_{2} \mathrm{O}_{2}$ is a known inductor of the RyR opening, but concentrations between $100 \mu \mathrm{M}$ and $10 \mathrm{mM}$ were necessary [66,67]. Although the $\mathrm{H}_{2} \mathrm{O}_{2}$ concentration was too low for triggering $\mathrm{Ca}^{2+}$ influx alone, it could still be involved in the CAP-induced effects on cancer cells. The fact that pretreatment of the melanoma cells with histidine, which scavenges $\mathrm{H}_{2} \mathrm{O}_{2}$, caused a significant reduction of CAP-induced cytoplasmic $\mathrm{Ca}^{2+}$ elevation supports this theory. In addition, the incubation of the cells with $\mathrm{pH} 6$ increased the sensitivity of melanoma cells to $\mathrm{H}_{2} \mathrm{O}_{2}$, whereby a Ca ${ }^{2+}$ influx in $10 \%$ of Mel Im and $7 \%$ of Mel Juso cells could be observed. The differential composition of routinely used media causes substantial differences in CAP-induced chemicals, e.g., $\mathrm{H}_{2} \mathrm{O}_{2}$ is markedly different between DMEM and RPMI. The manuscript used mainly minimal self-composed media to investigate particular components, as these have many ingredients, e.g., to support that glucose has no impact on CAP-induced species production.

In summary, we demonstrated the importance of CAP-induced acidification in CAP-induced intracellular $\mathrm{Ca}^{2+}$ elevation in malignant melanoma cells. The inhibition of acidification by stronger buffer systems reduced the CAP-induced $\mathrm{Ca}^{2+}$ influx. $\mathrm{HNO}_{3}$ and $\mathrm{HNO}_{2}$, which are produced by 
hydrolysis of CAP-induced $\mathrm{NO}_{2}$, are hypothesized to cause this acidification, as we could demonstrate a $\mathrm{pH}$-dependent $\mathrm{CAP}$-induced NO-production and protein nitration. The scavenger experiments revealed that ROS were equally involved in CAP-induced $\mathrm{Ca}^{2+}$ influx, which suggests a synergistic effect of CAP-induced ROS, RNS, and acidic conditions. The CAP generates a complex cocktail of unknown recipe, of which some essential ingredients were investigated; nevertheless, this will help to develop CAP as a possible cancer therapy. CAP treatment could be performed e.g., after the surgical removal of the tumor. The acidic conditions in tumors could support the CAP-effects and contribute to cancer cell-specificity.

\section{Materials and Methods}

\subsection{Cell Culture}

The Mel Juso cell line (DSMZ: ACC74) was established from a primary cutaneous melanoma and the Mel Im cell line, as obtained from Prof. Dr. Judith Johnson [68], was descended from a metastatic malignant melanoma. The DSMZ recently authenticated the cell lines. The cells were cultivated in RPMI 1640 (Mel Juso) and in Dulbecco's modified eagle's medium (DMEM, Mel Im) bought from Sigma-Aldrich, Steinheim, Germany, as described previously [69]. Mycoplasma contamination is excluded on a regular basis for both cell lines.

\subsection{Plasma Device}

The experiments were performed with a miniFlatPlaSter plasma device, which was developed by the Max Planck Institute for Extraterrestrial Physics (Garching, now Terraplasma GmbH, Garching, Germany) for treating tumor cells and tissue. The plasma is generated from ambient air using the SMD technology [2,5]. Technical details of the device have recently been published [70].

\subsection{Chemicals and Solutions}

The ECS, the pbECS, and further variations in solutions used in $\mathrm{Ca}^{2+}$ imaging experiments were freshly prepared, and Table 1 lists the components. The Ponceaus $\mathrm{S}$ solution was composed of $0.2 \%$ Ponceau S, 3\% trichloroacedic acid, and 3\% sulfosalicylic acid. Sources for chemicals and solutions: Dulbecco's phosphate buffered saline (DPBS) (Sigma-Aldrich, Steinheim, Germany), fura-2 AM and pluronic F-127 (Biotium, Fremont, CA, USA), ionomycin (2 $\mu \mathrm{M}$, Enzo Life Sciences, Farmingdale, NY, USA), DMSO (Sigma-Aldrich), histidine ( $3 \mu \mathrm{M}$, Sigma-Aldrich), $\mathrm{NaN}_{3}$ (Sigma-Aldrich), 30\% (w/w) $\mathrm{H}_{2} \mathrm{O}_{2}(6 \mu \mathrm{M}$, Sigma-Aldrich), cPTIO (250 $\mu \mathrm{M}$, Cayman Chemical, Ann Arbor, MI, US), anti-nitrotyrosine antibody (MERCK, Darmstadt, Germany, 06-284), and alkaline phosphatase-conjugated rabbit secondary antibody (Cell Signaling, Danvers, MA, USA, 7054S). Dihydrorhodamine 123 (DHR 123) and the Fluorimetic Hydrogen Peroxide Assay Kit both from Sigma-Aldrich, 4,5-diaminofluorescein (DAF-2) from Enzo Life Sciences (Farmingdale, NY, USA) and the Singlet Oxygen Sensor Green Reagent purchased from Molecular Probes (Eugene, OR, USA) were used to perform the fluorescence spectroscopic analyses of CAP-induced reactive species.

\section{4. $\mathrm{Ca}^{2+}$ Imaging}

The experimental approach has been performed, as previously described [26]. CAP treatment was executed in two ways: direct or indirect. The experimental set up was shown in a previous publication [26]. The only modification of the indirect CAP treatment method was a volume increase from $120 \mu \mathrm{L}$ to $140 \mu \mathrm{L}$ of the CAP-exposed solution, being deposited in seven separate $20 \mu \mathrm{L}$ droplets. As before, $100 \mu \mathrm{L}$ of the CAP-exposed solution was added to these cells.

For application experiments without CAP, the cells were washed in pbECS with $\mathrm{pH} 7.4$, unless stated otherwise. For titration experiments, seven separate $20 \mu \mathrm{L}$ drops of pbECS in a six-well plate without cells were exposed to $120 \mathrm{~s} C A P$ and transferred into a $1.5 \mathrm{~mL}$ reaction vessel. Immediately, $1 \mu \mathrm{L}$ pbECS or $1 \mu \mathrm{L} \mathrm{NaOH}(1 \mathrm{M})$ or $1 \mu \mathrm{L} \mathrm{NaOH}$ and $1 \mu \mathrm{L} \mathrm{HCl}$ (both $1 \mathrm{M}$ ) were added and mixed by 
vortexing. The test solution or titrated pbECS were applied into an aluminum ring of $6.5 \mathrm{~mm}$ diameter after $60 \mathrm{~s}$ of $\mathrm{Ca}^{2+}$ measurement.

The experimental setup and procedures were described in detail [71]. In brief, the fluorescence of fura-2-stained single cells was recorded while the sample was alternatingly excited at $358 \mathrm{~nm}$ and $391 \mathrm{~nm}$ with a frequency of $1 \mathrm{~Hz}$ with a Polychrome V monochromator (Till Photonics, München, Germany). A cooled charge-coupled device (CCD) camera collected a fluorescence emission above $440 \mathrm{~nm}$. The area under the curve (AUC) of the fluorescent time course of individual cells was calculated for a period of $120 \mathrm{~s}$ after stimulation by CAP treatment or a solution, the $10 \mathrm{~s}$ before this stimulation served as reference.

\subsection{Fluorescence Spectroscopic Detection of Reactive Species}

The fluorescence dyes DHR 123 (ROS-indicator), DAF-2 (NO-indicator), and the Singlet Oxygen Sensor Green Reagent were dissolved in the solution to be analyzed at a concentration of $10 \mu \mathrm{M}$. In a six-well plate (Corning Incorporated, Corning, NY, USA), seven separate $20 \mu \mathrm{L}$ drops of the respective solution were exposed to different CAP doses or remained untreated. Immediately after CAP treatment, $100 \mu \mathrm{L}$ of the solution was added to a black 96-well plate (Corning Incorporated) and the fluorescence was measured with the CLARIOstar ELISA-Reader (BMG LABTECH, Ortenberg, Germany) at $\mathrm{Ex}=500 \pm 8 \mathrm{~nm}$ und $\mathrm{Em}=530 \pm 8 \mathrm{~nm}$. $\mathrm{H}_{2} \mathrm{O}_{2}$ concentration was determined by using the Fluorimetic Hydrogen Peroxide Assay Kit. The analyzed solutions were added to a six-well plate in $7 \times 20 \mu \mathrm{L}$ drops and they were treated or not treated with CAP. A volume of $50 \mu \mathrm{L}$ of the CAP-exposed solution was transferred into a black $96-$ well plate. The further procedure was performed according to the manufactures protocol in duplicates. The fluorescence of the peroxidase substrate was measured at $\mathrm{Ex}=540 \mathrm{~nm}$ and $\mathrm{Em}=590 \mathrm{~nm}$ by using the CLARIOstar ELISA-Reader.

\subsection{Western Blot Analysis}

On the day before CAP treatment, 200,000 cells per six-well plate (direct CAP treatment, double well), or 50,000 cells per 24-well plate (indirect CAP treatment, four wells) were seeded. For titration experiments with indirect CAP treatment, seven separate $20 \mu \mathrm{L}$ drops of pbECS were exposed to 120 s CAP and titrated with $\mathrm{NaOH}$ or $\mathrm{HCl}$, as described under $\mathrm{Ca}^{2+}$ imaging. After a washing step with pbECS, the whole CAP-treated solution was applied onto the cells. Direct CAP treatment was only performed with a residual fluid ( $33 \pm 1 \mu \mathrm{m}$ fluid layer height) of DMEM or RPMI on the cells. Immediately thereafter, the cells were covered with $2 \mathrm{~mL}$ medium. After direct and indirect CAP treatment, followed an incubation of one hour at $37{ }^{\circ} \mathrm{C}$ and $8 \% \mathrm{CO}_{2}$. The radioimmunoprecipitation assay (RIPA) buffer was used to produce total protein lysates, as described previously [72]. The RIPA protein lysates were separated via sodium dodecyl sulphate polyacrylamide gel electrophoresis on a 10\% gel and blotted on a poly-vinylidene difluoride (PVDF) membrane. For Ponceau staining, the membrane was briefly activated with pure methanol and then washed with bidestilled water. The membrane was incubated for $15 \mathrm{~min}$. in a $0.2 \%$ Ponceau S solution and the excess dye was carefully removed with bidestilled water. The Ponceau staining was captured with a Perfection V800 scanner (Seiko Epson Corporation, Suwa, Japan). After another washing step with bidestilled water, the membrane was incubated for one hour in the blocking buffer containing $5 \%$ milk powder and Tris-buffered saline with $0.1 \%$ tween (TBS-T). The membrane was incubated over night with the primary anti-nitrotyrosine antibody (1:1000, MERCK, 06-284), in TBS-T, followed by an incubation of $1 \mathrm{~h}$ at room temperature with the alkaline phosphatase-conjugated rabbit secondary antibody (Cell Signaling, 7054S) 1:3000 in TBS-T. The Claity ${ }^{\mathrm{TM}}$ Western ECL Substrate was used to perform protein visualization (Bio-Rad, Hercules, CA, USA).

\section{7. $\mathrm{pH}$ Measurement}

For $\mathrm{pH}$ measurement, $7 \times 20 \mu \mathrm{L}$ drops of the respective solution in $35 \mathrm{~mm}$ diameter tissue culture dishes (Sarstedt, Nümbrecht, Germany) were exposed to CAP and then transferred into a $1.5 \mathrm{~mL}$ 
reaction vessel. The $\mathrm{pH}$ measurement was performed immediately by using the LAQUAtwin $\mathrm{pH}$ meter (HORIBA Scientific, Kyōto, Japan).

\subsection{Statistical Analysis}

Two groups with at least ten samples were compared with a paired or unpaired t-test, and smaller independent groups with a U-test. Repeated measurements and multiple groups were compared by ANOVA and HSD post-hoc tests. The parametric association between variables was quantified by a product-momentum correlation. Statistica 8 (Statsoft, Tulsa, OK, USA) or GraphPad Prism 5 (GraphPad Software Inc., San Diego, CA, USA) were used for statistical analysis. Time courses and AUCs are presented with mean and $99 \%$ confidence intervals, other results with mean \pm SEM, except for; $p<0.05$ was considered to be significant.

\section{Conclusions}

We could show in this study that a synergistic effect of CAP-induced ROS, RNS and acidic conditions affect the intracellular $\mathrm{Ca}^{2+}$ homeostasis of melanoma cells. As the microenvironment of tumors is often acidic, this might be one reason for the specific anti-cancer effects of CAP.

Supplementary Materials: The following are available online at http://www.mdpi.com/2072-6694/11/5/671/s1, Figure S1: The CAP-induced intracellular $\mathrm{Ca}^{2+}$ influx is $\mathrm{pH}$ dependent, Figure S2: CAP-produced reactive species vary in different media, Figure S3: The CAP-induced acidification could be inhibited by $\mathrm{NaN}_{3}$, Figure S4: Application of $\mathrm{H}_{2} \mathrm{O}_{2}$ onto melanoma cells causes a minor $\mathrm{Ca}^{2+}$ influx, Figure S5: Whole blots of the Western Blot analysis of CAP-induced protein nitration after direct CAP treatment of Mel Im and Mel Juso cells, shown in Figure 4F, Table S1: Densitometric evaluation of the Western Blot analysis shown in Figure 4F,G.

Author Contributions: C.S., L.G., M.J.M.F., A.-K.B.; Methodology, C.S., L.G., M.J.M.F., A.-K.B.; Formal Analysis, C.S., L.G., M.J.M.F; Investigation, C.S., L.G; Resources, J.L.Z., M.J.M.F., A.-K.B.; Writing-Original Draft, C.S, L.G., M.J.M.F., A.-K.B.; Writing-Review \& Editing, C.S., L.G., S.A., S.K., M.J.M.F., A.-K.B.; Visualization: C.S., L.G., M.J.M.F.; Supervision, M.J.M.F. and A.-K.B.; Funding Acquisition, M.J.M.F. and A.-K.B.

Funding: This work was supported by the German Research Association (DFG) (BO1573), the German Cancer Aid and the Interdisciplinary Center for Clinical Research (IZKF) Erlangen (D24 and E27).

Acknowledgments: We thank Birgit Vogler and Michaela Pommer for great technical support.

Conflicts of Interest: The authors declare no conflict of interest.

\section{References}

1. Heinlin, J.; Isbary, G.; Stolz, W.; Morfill, G.; Landthaler, M.; Shimizu, T.; Steffes, B.; Nosenko, T.; Zimmermann, J.L.; Karrer, S. Plasma applications in medicine with a special focus on dermatology. J. Eur. Acad. Dermatol. Venereol. 2011, 25, 1-11. [CrossRef]

2. Morfill, G.E.; Shimizu, T.; Steffes, B.; Schmidt, H.U. Nosocomial infections-A new approach towards preventive medicine using plasmas. New J. Phys. 2009, 11. [CrossRef]

3. Zimmermann, J.L.; Dumler, K.; Shimizu, T.; Morfill, G.E.; Wolf, A.; Boxhammer, V.; Schlegel, J.; Gansbacher, B.; Anton, M. Effects of cold atmospheric plasmas on adenoviruses in solution. J. Phys. D Appl. Phys. 2011, $44,505201$.

4. Maisch, T.; Shimizu, T.; Isbary, G.; Heinlin, J.; Karrer, S.; Klämpfl, T.G.; Li, Y.F.; Morfill, G.; Zimmermann, J.L. Contact-free inactivation of Candida albicans biofilms by cold atmospheric air plasma. Appl. Environ. Microbiol. 2012, 78, 4242-4247. [PubMed]

5. Maisch, T.; Shimizu, T.; Li, Y.F.; Heinlin, J.; Karrer, S.; Morfill, G.; Zimmermann, J.L. Decolonisation of MRSA, S. aureus and E. coli by cold-atmospheric plasma using a porcine skin model in vitro. PLoS ONE 2012, 7, e34610. [CrossRef]

6. Klämpfl, T.G.; Isbary, G.; Shimizu, T.; Li, Y.F.; Zimmermann, J.L.; Stolz, W.; Schlegel, J.; Morfill, G.E.; Schmidt, H.U. Cold atmospheric air plasma sterilization against spores and other microorganisms of clinical interest. Appl. Environ. Microbiol. 2012, 78, 5077-5082. [CrossRef] 
7. Isbary, G.; Heinlin, J.; Shimizu, T.; Zimmermann, J.L.; Morfill, G.; Schmidt, H.U.; Monetti, R.; Steffes, B.; Bunk, W.; Li, Y.; et al. Successful and safe use of 2 min cold atmospheric argon plasma in chronic wounds: Results of a randomized controlled trial. Br. J. Dermatol. 2012, 167, 404-410. [CrossRef] [PubMed]

8. Arndt, S.; Unger, P.; Berneburg, M.; Bosserhoff, A.-K.; Karrer, S. Cold atmospheric plasma (CAP) activates angiogenesis-related molecules in skin keratinocytes, fibroblasts and endothelial cells and improves wound angiogenesis in an autocrine and paracrine mode. J. Dermatol. Sci. 2018, 89, 181-190. [CrossRef] [PubMed]

9. Chatraie, M.; Torkaman, G.; Khani, M.; Salehi, H.; Shokri, B. In vivo study of non-invasive effects of non-thermal plasma in pressure ulcer treatment. Sci. Rep. 2018, 8, 5621. [CrossRef]

10. Arndt, S.; Unger, P.; Wacker, E.; Shimizu, T.; Heinlin, J.; Li, Y.-F.; Thomas, H.M.; Morfill, G.E.; Zimmermann, J.L.; Bosserhoff, A.-K.; Karrer, S. Cold atmospheric plasma (CAP) changes gene expression of key molecules of the wound healing machinery and improves wound healing in vitro and in vivo. PLoS One 2013, 8, e79325. [CrossRef]

11. Yan, D.; Sherman, J.H.; Keidar, M. Cold atmospheric plasma, a novel promising anti-cancer treatment modality. Oncotarget 2017, 8, 15977-15995. [CrossRef]

12. Corrie, P.; Hategan, M.; Fife, K.; Parkinson, C. Management of melanoma. Br. Med. Bull. 2014, 111, $149-162$. [CrossRef] [PubMed]

13. Arndt, S.; Wacker, E.; Li, Y.F.; Shimizu, T.; Thomas, H.M.; Morfill, G.E.; Karrer, S.; Zimmermann, J.L.; Bosserhoff, A.K. Cold atmospheric plasma, a new strategy to induce senescence in melanoma cells. Exp. Dermatol. 2013, 22, 284-289. [CrossRef] [PubMed]

14. Köritzer, J.; Boxhammer, V.; Schäfer, A.; Shimizu, T.; Klämpfl, T.G.; Li, Y.-F.; Welz, C.; Schwenk-Zieger, S.; Morfill, G.E.; Zimmermann, J.L.; Schlegel, J. Restoration of sensitivity in chemo-resistant glioma cells by cold atmospheric plasma. PLoS ONE 2013, 8, e64498. [CrossRef]

15. Kim, G.J.; Kim, W.; Kim, K.T.; Lee, J.K. DNA damage and mitochondria dysfunction in cell apoptosis induced by nonthermal air plasma. Appl. Phys. Lett. 2010, 96, 021502. [CrossRef]

16. Ishaq, M.; Kumar, S.; Varinli, H.; Han, Z.J.; Rider, A.E.; Evans, M.D.M.; Murphy, A.B.; Ostrikov, K. Atmospheric gas plasma-induced ROS production activates TNF-ASK1 pathway for the induction of melanoma cancer cell apoptosis. Mol. Biol. Cell 2014, 25, 1523-1531. [CrossRef]

17. Ahn, H.J.; Kim, K., II; Kim, G.; Moon, E.; Yang, S.S.; Lee, J.-S. Atmospheric-pressure plasma jet induces apoptosis involving mitochondria via generation of free radicals. PLoS ONE 2011, 6, e28154. [CrossRef]

18. Tanaka, H.; Mizuno, M.; Ishikawa, K.; Nakamura, K.; Kajiyama, H.; Kano, H.; Kikkawa, F.; Hori, M. Plasma-activated medium selectively kills glioblastoma brain tumor cells by down-regulating a survival signaling molecule, AKT kinase. Plasma Med. 2011, 1, 265-277. [CrossRef]

19. Kumar, N.; Park, J.H.; Jeon, S.N.; Park, B.S.; Choi, E.H.; Attri, P. The action of microsecond-pulsed plasma-activated media on the inactivation of human lung cancer cells. J. Phys. D Appl. Phys. 2016, 49, 115401. [CrossRef]

20. Chen, Z.; Lin, L.; Gjika, E.; Cheng, X.; Canady, J.; Keidar, M. Selective treatment of pancreatic cancer cells by plasma-activated saline solutions. IEEE Trans. Radiat. Plasma Med. Sci. 2018, 2, 116-120. [CrossRef]

21. Panngom, K.; Baik, K.Y.; Nam, M.K.; Han, J.H.; Rhim, H.; Choi, E.H. Preferential killing of human lung cancer cell lines with mitochondrial dysfunction by nonthermal dielectric barrier discharge plasma. Cell Death Dis. 2013, 4, e642. [CrossRef]

22. Keidar, M.; Shashurin, A.; Volotskova, O.; Ann Stepp, M.; Srinivasan, P.; Sandler, A.; Trink, B. Cold atmospheric plasma in cancer therapy. Phys. Plasmas 2013, 20. [CrossRef]

23. Zucker, S.N.; Zirnheld, J.; Bagati, A.; DiSanto, T.M.; Des Soye, B.; Wawrzyniak, J.A.; Etemadi, K.; Nikiforov, M.; Berezney, R. Preferential induction of apoptotic cell death in melanoma cells as compared with normal keratinocytes using a non-thermal plasma torch. Cancer Biol. Ther. 2012, 13, 1299-1306. [CrossRef] [PubMed]

24. Utsumi, F.; Kajiyama, H.; Nakamura, K.; Tanaka, H.; Mizuno, M.; Ishikawa, K.; Kondo, H.; Kano, H.; Hori, M.; Kikkawa, F. Effect of indirect nonequilibrium atmospheric pressure plasma on anti-proliferative activity against chronic chemo-resistant ovarian cancer cells in vitro and in vivo. PLoS ONE 2013, 8, e81576. [CrossRef] [PubMed]

25. Ishaq, M.; Han, Z.J.; Kumar, S.; Evans, M.D.M.; Ostrikov, K.K. Atmospheric-pressure plasma- and trail-induced apoptosis in trail-resistant colorectal cancer cells. Plasma Process. Polym. 2015, 12, 574-582. [CrossRef] 
26. Schneider, C.; Gebhardt, L.; Arndt, S.; Karrer, S.; Zimmermann, J.L.; Fischer, M.J.M.; Bosserhoff, A.-K. Cold atmospheric plasma causes a calcium influx in melanoma cells triggering CAP-induced senescence. Sci. Rep. 2018, 8, 10048. [CrossRef]

27. Jablonowski, H.; von Woedtke, T. Research on plasma medicine-relevant plasma-liquid interaction: What happened in the past five years? Clin. Plasma Med. 2015, 3, 42-52. [CrossRef]

28. Cai, Q.; Takemura, G.; Ashraf, M. Antioxidative properties of histidine and its effect on myocardial injury during ischemia/reperfusion in isolated rat heart. J. Cardiovasc. Pharmacol. 1995, 25, 147-155. [CrossRef]

29. Matheson, I.B.C.; Etheridge, R.D.; Kratowich, N.R.; Lee, J. The quenching of singlet oxygen by amino acids and proteins. Photochem. Photobiol. 1975, 21, 165-171. [CrossRef]

30. Cooper, W.J.; Zepp, R.G. Hydrogen peroxide decay in waters with suspended soils: Evidence for biologically mediated processes. Can. J. Fish. Aquat. Sci. 1990, 47, 888-893. [CrossRef]

31. Böhme, I.; Bosserhoff, A.K. Acidic tumor microenvironment in human melanoma. Pigment Cell Melanoma Res. 2016, 29, 508-523. [CrossRef] [PubMed]

32. Hashim, A.I.; Zhang, X.; Wojtkowiak, J.W.; Martinez, G.V.; Gillies, R.J. Imaging pH and metastasis. NMR Biomed. 2011, 24, 582-591. [CrossRef]

33. Meyer, K.A.; Kammerling, E.M.; Amtman, L.; Koller, M.; Hoffman, S.J. pH studies of malignant tissues in human beings. Cancer Res. 1948, 8, 513-518.

34. Vaupel, P.; Kallinowski, F.; Okunieff, P. Blood flow, oxygen and nutrient supply, and metabolic microenvironment of human tumors: A review. Cancer Res. 1989, 49, 6449-6465. [PubMed]

35. Smith, J.B.; Dwyer, S.D.; Smith, L. Lowering extracellular pH evokes inositol polyphosphate formation and calcium mobilization. J. Biol. Chem. 1989, 264, 8723-8728.

36. Fischer, M.J.M.; Reeh, P.W.; Sauer, S.K. Proton-induced calcitonin gene-related peptide release from rat sciatic nerve axons, in vitro, involving TRPV1. Eur. J. Neurosci. 2003, 18, 803-810. [CrossRef]

37. Ivanov, I.; Gadjeva, V. Influence of some DNA-alkylating drugs on thermal stability, acid and osmotic resistance of the membrane of whole human erythrocytes and their ghosts. Pharmazie 2000, 55, 672-677. [PubMed]

38. Ercan, U.K.; Wang, H.; Ji, H.; Fridman, G.; Brooks, A.D.; Joshi, S.G. Nonequilibrium plasma-activated antimicrobial solutions are broad-spectrum and retain their efficacies for extended period of time. Plasma Process. Polym. 2013, 10, 544-555. [CrossRef]

39. Oehmigen, K.; Hähnel, M.; Brandenburg, R.; Wilke, C.; Weltmann, K.-D.; von Woedtke, T. The role of acidification for antimicrobial activity of atmospheric pressure plasma in liquids. Plasma Process. Polym. 2010, 7, 250-257. [CrossRef]

40. Zhunussova, A.; Vitol, E.A.; Polyak, B.; Tuleukhanov, S.; Brooks, A.D.; Sensenig, R.; Friedman, G.; Orynbayeva, Z. Mitochondria-mediated anticancer effects of non-thermal atmospheric plasma. PLoS ONE 2016, 11, 1-15. [CrossRef]

41. Hensel, K.; Kučerová, K.; Tarabová, B.; Janda, M.; Machala, Z.; Sano, K.; Mihai, C.T.; Ciorpac, M.; Gorgan, L.D.; Jijie, R.; Pohoata, V.; Topala, I. Effects of air transient spark discharge and helium plasma jet on water, bacteria, cells, and biomolecules. Biointerphases 2015, 10. [CrossRef]

42. Tresp, H.; Hammer, M.U.; Weltmann, K.-D.; Reuter, S. Effects of atmosphere composition and liquid type on plasma-generated reactive species in biologically relevant solutions. Plasma Med. 2013, 3, 45-55. [CrossRef]

43. Oehmigen, K.; Winter, J.; Hähnel, M.; Wilke, C.; Brandenburg, R.; Weltmann, K.-D.; von Woedtke, T. Estimation of possible mechanisms of escherichia coli inactivation by plasma treated sodium chloride solution. Plasma Process. Polym. 2011, 8, 904-913. [CrossRef]

44. Chih, W.C.; How-Ming, L.; Moo Been, C. Inactivation of aquatic microorganisms by low-frequency ac discharges. IEEE Trans. Plasma Sci. 2008, 36, 215-219. [CrossRef]

45. Helmke, A.; Hoffmeister, D.; Mertens, N.; Emmert, S.; Schuette, J.; Vioel, W. The acidification of lipid film surfaces by non-thermal DBD at atmospheric pressure in air. New J. Phys. 2009, 11, 115025. [CrossRef]

46. Suschek, C.V.; Opländer, C. The application of cold atmospheric plasma in medicine: The potential role of nitric oxide in plasma-induced effects. Clin. Plasma Med. 2016, 4, 1-8. [CrossRef]

47. van Gils, C.A.J.; Hofmann, S.; Boekema, B.K.H.L.; Brandenburg, R.; Bruggeman, P.J. Mechanisms of bacterial inactivation in the liquid phase induced by a remote RF cold atmospheric pressure plasma jet. J. Phys. D Appl. Phys. 2013, 46. [CrossRef] 
48. Park, J.Y.; Lee, Y.N. Solubility and decomposition kinetics of nitrous acid in aqueous solution. J. Phys. Chem. 1988, 92, 6294-6302. [CrossRef]

49. Lukes, P.; Dolezalova, E.; Sisrova, I.; Clupek, M. Aqueous-phase chemistry and bactericidal effects from an air discharge plasma in contact with water: Evidence for the formation of peroxynitrite through a pseudo-second-order post-discharge reaction of $\mathrm{H} 2 \mathrm{O} 2$ and HNO2. Plasma Sources Sci. Technol. 2014, 23. [CrossRef]

50. Marouf-Khelifa, K.; Abdelmalek, F.; Khelifa, A.; Belhadj, M.; Addou, A.; Brisset, J.-L. Reduction of nitrite by sulfamic acid and sodium azide from aqueous solutions treated by gliding arc discharge. Sep. Purif. Technol. 2006, 50, 373-379. [CrossRef]

51. Van Boxem, W.; Van der Paal, J.; Gorbanev, Y.; Vanuytsel, S.; Smits, E.; Dewilde, S.; Bogaerts, A. Anti-cancer capacity of plasma-treated PBS: effect of chemical composition on cancer cell cytotoxicity. Sci. Rep. 2017, 7, 16478. [CrossRef] [PubMed]

52. Machala, Z.; Tarabova, B.; Hensel, K.; Spetlikova, E.; Sikurova, L.; Lukes, P. Formation of ROS and RNS in water electro-sprayed through transient spark discharge in air and their bactericidal effects. Plasma Process. Polym. 2013, 10, 649-659. [CrossRef]

53. Zhao, G.; Chasteen, N.D. Oxidation of Good's buffers by hydrogen peroxide. Anal. Biochem. 2006, 349, 262-267. [CrossRef] [PubMed]

54. Ferrer-Sueta, G.; Campolo, N.; Trujillo, M.; Bartesaghi, S.; Carballal, S.; Romero, N.; Alvarez, B.; Radi, R. Biochemistry of peroxynitrite and protein tyrosine nitration. Chem. Rev. 2018, 118, 1338-1408. [CrossRef] [PubMed]

55. Radi, R. Protein tyrosine nitration: Biochemical mechanisms and structural basis of functional effects. Acc. Chem. Res. 2013, 46, 550-559. [CrossRef] [PubMed]

56. Yamakura, F.; Taka, H.; Fujimura, T.; Murayama, K. Inactivation of human manganese-superoxide dismutase by peroxynitrite is caused by exclusive nitration of tyrosine 34 to 3-nitrotyrosine. J. Biol. Chem. 1998, 273, 14085-14089. [CrossRef]

57. MacMillan-Crow, L.A.; Crow, J.P.; Kerby, J.D.; Beckman, J.S.; Thompson, J.A. Nitration and inactivation of manganese superoxide dismutase in chronic rejection of human renal allografts. Proc. Natl. Acad. Sci. USA 1996, 93, 11853-11858. [CrossRef]

58. Naïtali, M.; Kamgang-Youbi, G.; Herry, J.-M.; Bellon-Fontaine, M.-N.; Brisset, J.-L. Combined effects of long-living chemical species during microbial inactivation using atmospheric plasma-treated water. Appl. Environ. Microbiol. 2010, 76, 7662-7664. [CrossRef]

59. Butler, A.R.; Feelisch, M. Therapeutic uses of inorganic nitrite and nitrate: from the past to the future. Circulation 2008, 117, 2151-2159. [CrossRef] [PubMed]

60. Zweier, J.L.; Samouilov, A.; Kuppusamy, P. Non-enzymatic nitric oxide synthesis in biological systems. Biochim. Biophys. Acta 1999, 1411, 250-262. [CrossRef]

61. Pfeiffer, S.; Mayer, B. Lack of tyrosine nitration by peroxynitrite generated at physiological Ph. J. Biol. Chem. 1998, 273, 27280-27285. [CrossRef] [PubMed]

62. Ikawa, S.; Kitano, K.; Hamaguchi, S. Effects of $\mathrm{pH}$ on bacterial inactivation in aqueous solutions due to low-temperature atmospheric pressure plasma application. Plasma Process. Polym. 2010, 7, 33-42. [CrossRef]

63. Kurake, N.; Tanaka, H.; Ishikawa, K.; Kondo, T.; Sekine, M.; Nakamura, K.; Kajiyama, H.; Kikkawa, F.; Mizuno, M.; Hori, M. Cell survival of glioblastoma grown in medium containing hydrogen peroxide and/or nitrite, or in plasma-activated medium. Arch. Biochem. Biophys. 2016, 605, 102-108. [CrossRef] [PubMed]

64. Girard, P.-M.; Arbabian, A.; Fleury, M.; Bauville, G.; Puech, V.; Dutreix, M.; Sousa, J.S. Synergistic effect of $\mathrm{H} 2 \mathrm{O} 2$ and NO2 in cell death induced by cold atmospheric He plasma. Sci. Rep. 2016, 6, 1-17. [CrossRef]

65. Sasaki, S.; Kanzaki, M.; Kaneko, T. Calcium influx through TRP channels induced by short-lived reactive species in plasma-irradiated solution. Sci. Rep. 2016, 6, 1-11. [CrossRef] [PubMed]

66. Boraso, A.; Williams, A.J. Modification of the gating of the cardiac sarcoplasmic reticulum $\mathrm{Ca}(2+)$-release channel by $\mathrm{H} 2 \mathrm{O} 2$ and dithiothreitol. Am. J. Physiol. 1994, 267, H1010-H1016. [CrossRef]

67. Favero, T.G.; Zable, A.C.; Abramson, J.J. Hydrogen peroxide stimulates the Ca2+ release channel from skeletal muscle sarcoplasmic reticulum. J. Biol. Chem. 1995, 270, 25557-25563. [CrossRef]

68. Johnson, J.P.; Demmer-Dieckmann, M.; Meo, T.; Hadam, M.R.; Riethmüller, G. Surface antigens of human melanoma cells defined by monoclonal antibodies. I. Biochemical characterization of two antigens found on cell lines and fresh tumors of diverse tissue origin. Eur. J. Immunol. 1981, 11, 825-831. [CrossRef] 
69. Limm, K.; Dettmer, K.; Reinders, J.; Oefner, P.J.; Bosserhoff, A.K. Characterization of the methylthioadenosine phosphorylase polymorphism rs7023954-Incidence and effects on enzymatic function in malignant melanoma. PLOS ONE 2016, 11, 1-13. [CrossRef]

70. Schneider, C.; Arndt, S.; Zimmermann, J.L.; Li, Y.; Karrer, S.; Bosserhoff, A.K. Cold atmospheric plasma treatment inhibits growth in colorectal cancer cells. Biol. Chem. 2018, 400, 111-122. [CrossRef]

71. Babes, A.; Sauer, S.K.; Moparthi, L.; Kichko, T.I.; Neacsu, C.; Namer, B.; Filipovic, M.; Zygmunt, P.M.; Reeh, P.W.; Fischer, M.J.M. Photosensitization in porphyrias and photodynamic therapy involves TRPA1 and TRPV1. J. Neurosci. 2016, 36, 5264-5278. [CrossRef]

72. Stieglitz, D.; Lamm, S.; Braig, S.; Feuerer, L.; Kuphal, S.; Dietrich, P.; Arndt, S.; Echtenacher, B.; Hellerbrand, C.; Karrer, S.; Bosserhoff, A.K. BMP6-induced modulation of the tumor micro-milieu. Oncogene 2019, 38, 609-621. [CrossRef] [PubMed]

(C) 2019 by the authors. Licensee MDPI, Basel, Switzerland. This article is an open access article distributed under the terms and conditions of the Creative Commons Attribution (CC BY) license (http://creativecommons.org/licenses/by/4.0/). 